AWEJ for Translation \& Literary Studies, Volume 5, Number4. October 2021 DOI: http://dx.doi.org/10.24093/awejtls/vol5no4.3

Pp. 27-45

\title{
Investigating the Translation Strategies Used in Rendering Cultural Bound Expressions in Barghouthy's Memoire I Was Born There, I Was Born Here
}

\author{
Mohammed S. El Haj Ahmed \\ Department of English \\ Islamic University of Gaza, Gaza, PNA \\ Rola A. Mansour \\ Department of English \\ Gaza University of Gaza, Gaza, PNA
}

Received: 8/8/2021

Accepted: 9/29/2021

Published: 10/24/2021

\begin{abstract}
This study investigates the translation strategies used in translating 25 cultural references and expressions in Mourid Barghouty's autobiography 'I Was Born There, I Was Born Here' (2009) from Arabic into English. The results of this research may assist the trainee translators to improve their understanding of the effect of culture on the quality of the translation. The researchers adopt two theoretical models: Venuti's domestication and foreignization (1998) and Ivir's (1987) procedures for the translation of cultural references. This study tries to find out to what extent the translation has accounted to render the original cultural bound expressions maintaining their meaning in the target language. The researchers adopt a qualitative research since the data analysis is based on analytical and descriptive approaches. After analyzing the selected data, the researchers find out that the domestication strategy has been the most frequently-used strategy at (52\%), and foreignization comes second at $(48 \%)$. The procedure of substitution has been used the most (seven times), followed by literal translation and borrowing with the same number of times (six times), then defining the elements of culture (four times), then omission (twice). Lexical creation and addition have not been used at all. The findings also show that the translator has managed to capture the intended meaning sought by the original author in most extracts. The researchers recommend that translators of culture-bound expressions should be aware of the two involved cultures. This helps them to determine the cultural context in which a text takes place, so they can achieve the closest equivalents in the target text.
\end{abstract}

Keywords: cultural bound expressions, domestication, foreignization, qualitative research, translation strategies

Cite as: Ahmed, M. S. E., \& Mansour, R. A. (2021). Investigating the Translation Strategies Used in Rendering Cultural Bound Expressions in Barghouthy's Memoire I Was Born There, I Was Born Here. Arab World English Journal for Translation \& Literary Studies 5 (4) 27-45. DOI: http://dx.doi.org/10.24093/awejtls/vol5no4.3 


\section{Introduction}

Mourid El-Barghouthy (1944-2021) is a Palestinian poet who has spent a long time of his life in exile, and in 1996 he was allowed to return to Palestine. I Was Born There, I Was Born Here is an autobiographical novel published in 2009 as a second part of Barghouthy's memoire after publishing his great novel I Saw RamAllah, a story that began when Barghouty returned to the occupied Palestine to introduce his son, Tamim, to his homeland for the first time. In this book, Barghouthy talks about his family's suffering due to the Israeli occupation, and he tells a lot of stories that show his nostalgia to old days when the people of his village used to get together as one family.

Translation is a means of communication through which people can easily interact and exchange knowledge. However, translators face some challenges when they try to translate texts containing cultural and idiomatic expressions. The main problem in rendering such expressions is in rendering the actual meaning of the source text (ST) into the target text (TT). In the same context, Nida (1964) has stated that "in order to achieve an equivalent response, the translation should make sense; convey the spirit and the manner of the original; have natural and easy form of expressions" (p. 164). Translating CBEs requires that the translator should carefully look into the concept of culture since this type of expressions is very sensitive, and mistranslation in this case may cause very serious consequences. This novel is full of social conversations and dialogues that reflect the Palestinian culture. The researchers in this study highlight and analyze the strategies used in rendering such CBEs. Undoubtedly, translating cultural items is very challenging, especially when the two involved languages have totally different cultures.

The researchers found that Barghothy's memoire is worth studying since it deals with many culture-bound expressions whose translation is problematic for translators. The problem lies in that Arabic biographies have its own cultural concepts and atheistic features that are used in certain situations in Arab countries. Therefore, it is hard, to some extent, to render such type of writing into another language, especially a language that has different cultural aspects like English. The main problem here is that it is not easy to find an appropriate equivalent of a cultural term in the target language when translating a text that has cultural features. At this point, the researchers investigate the strategies used in translating cultural-bound expressions in Barghouthy's I Was Born There, I Was Born Here from Arabic into English.

The results of this research may assist the trainee translators to improve their understanding of the effect of culture on the quality of the translation. The findings will also be of particular significance to syllabus designers to get familiar with the most common translation strategies used in translating CBEs in light of Venuti's (1998) domestication and foreignization and Ivir's ( 1987) seven strategies of the translation of cultural references, including borrowing, defining the elements of culture, lexical creation, literal translation, omission, addition and substitution.

This thesis attempts to achieve the following main objectives:

1- Identifying the most common translation strategies used in translating cultural bound expressions (CBEs) in Barghouty's autobiography I Was Born There, I Was Born Here from Arabic into English. 
2- Finding out to what extent the translation has accounted for rendering the original cultural bound expressions maintaining their meaning in the target language.

The study tries to answer the following questions:

1- What are the most common translation strategies used in translating cultural bound expressions in Barghouty's autobiography I Was Born There, I Was Born Here from Arabic into English?

2- To what extent has the translation accounted for rendering the original cultural bound expressions maintaining their meaning in the target language?

3- What suggestions can be made to improve the inaccurate translations?

\section{Literature Review}

Literary translation is the translation of poetry, plays, songs, novels, as well as literary books, short stories, etc. Every author has his own style manifested in his writing; however, some opinions say that a translation has to maintain the style of the source text while others emphasize that a translation must adopt the style of the translator. According to Bush (1998), literary translation is "an original subjective activity at the center of a complex network of social and cultural practices" (p.127).

Translators face real problems and great challenges when they deal with literary texts, the most prominent of which are the issue of equivalence and untranslatability. As Gorjan (1970) has commented, "Translators can strive to come as close to the original as possible, but they never can or will achieve complete identity in their translations"(p. 201). Generally, the main task of the translator is to capture the meaning and the sense of the source text because as it has already been mentioned before, translation is not just rendering words and terms from one language into another, but it goes beyond linguistic boundaries.

There are still opinions that debate that translation is a linguistic activity, and culture does not have a role in the translation process. In response to that claim, Sapir (1949) has said that "language is a guide to social facts"(p. 72); which is true because language is a vehicle through which we express our thoughts, including cultural and social facts. A translator is a cultural mediator who translates the source culture into the target culture choosing the appropriate equivalence to serve the communicative function of the translation. Moreover, the translator sometimes interferes in the text in terms of taking some decisions to make the target text more natural and smoother in the target culture. Thus, some scholars say that the translator should be an inventive writer who rewrites the original text to make it suits the conventions of the target language, but he/she should not totally neglect the source culture.

Culture-bound terms have been defined by Harvey (2003) as "the terms which refer to concepts, institutions and personnel which are specific to the SL culture" (pp.2-6). In the previous definition culture-bound expressions seem to be limited or valid only within a particular culture. However, different cultures may have various interpretations of the same situation or the same symbol, even we may encounter some situations in the culture of the source language that are not found in the culture of the target language. For instance, the "white color" is a symbol of purity and happiness in some cultures, yet it is a symbol of sadness in other cultures. So the linguistic choices of any 
social group are highly related to the conventions and customs of its culture, and it will be, to some extent, impossible to render a text if the cultural context is ignored.

It is certain that bilingualism is required for translation proficiency and efficiency, but it is not enough since the good translator has to be bicultural or multicultural in order to know how to fix the problems resulting from the cultural differences between languages. Nida (2001) has pointed out that "For truly successful translation, biculturalism is even more important than bilingualism since the words only have meanings in terms of the cultures in which they function" (p.82). Nord (2001) asserts that "translating means comparing cultures" (p.34). Cultural gaps between the ST and the TT pose huge challenges for translators.

Untranslatability is a common problem in translating culture-bound expressions from Arabic into English and it is one of the prominent cultural restrictions and linguistic constraints. It means that a certain situation in the source text may not exist in the target text; in this situation the translator faces untranslatable words, the thing that urges him/her to find proper solutions to overcome such obstacles. Guerra (2015) has proposed a list of strategies which are practical solutions for texts with textual nature, including generalization, paraphrasing, omission and descriptive translation. For instance, if we want to translate the word تيمح into English, which is completely missing in the TL culture, we resort to paraphrasing it into TL by describing it conceptually as making ablution with earth by Muslims when water is scarce or missing. By doing so we can bridge the lexical and cultural gap between Arabic and English, making sure that this explanatory footnote will provide the target language reader with enough background information to enable him /her to grasp the SL cultural expression.

Domestication is the type of translation in which a transparent, fluent style is adopted to minimize the strangeness of the foreign text for target language readers, while foreignization means a target text is produced which deliberately breaks target conventions by retaining something of the foreignness of the original (Shuttleworth \& Cowie 1997).

Kouider Abbad (2016) is one of the Arab researchers who has addressed the issue of foreignization and domestication strategies. He planned to investigate the procedures and methods translators employ when translating certain cultural elements in Ahlam Mostaghanemi's novel "Memory of Body". A qualitative method was adopted to investigate the selected sample in this study. The researcher concluded that the foreignization strategy was the most common strategy used because it was chosen intentionally by both translators to preserve the identity of the Algerian Arabic culture. The most used procedures in the translation of cultural items in this study are: preservation, localization and addition.

\section{Data Analysis and Discussion}

The researchers classified Ivir's procedures for the translation of cultural references according to whether each procedure domesticates the source text or foreignizes it. Foreignization strategy can be applied in two basic procedures namely; borrowing and literal translation, as shown in figure one: 


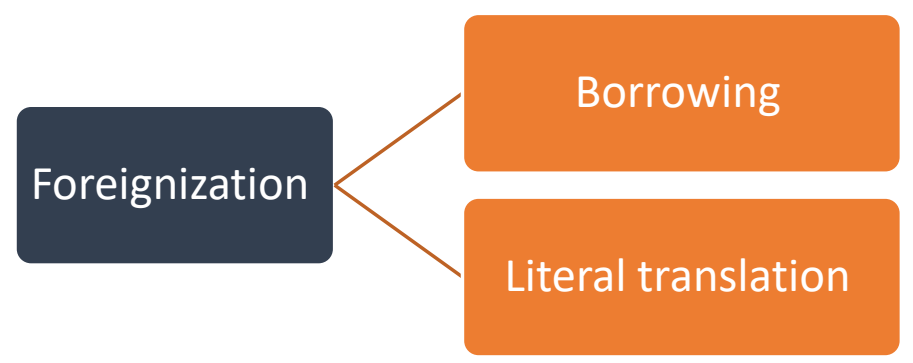

Figure one. Translation Procedures Foreignizing the Text

On the other hand, domestication strategy can be applied in five basic procedures namely, substitution, addition, omission, lexical creation and defining the elements of culture, as shown in figure two:

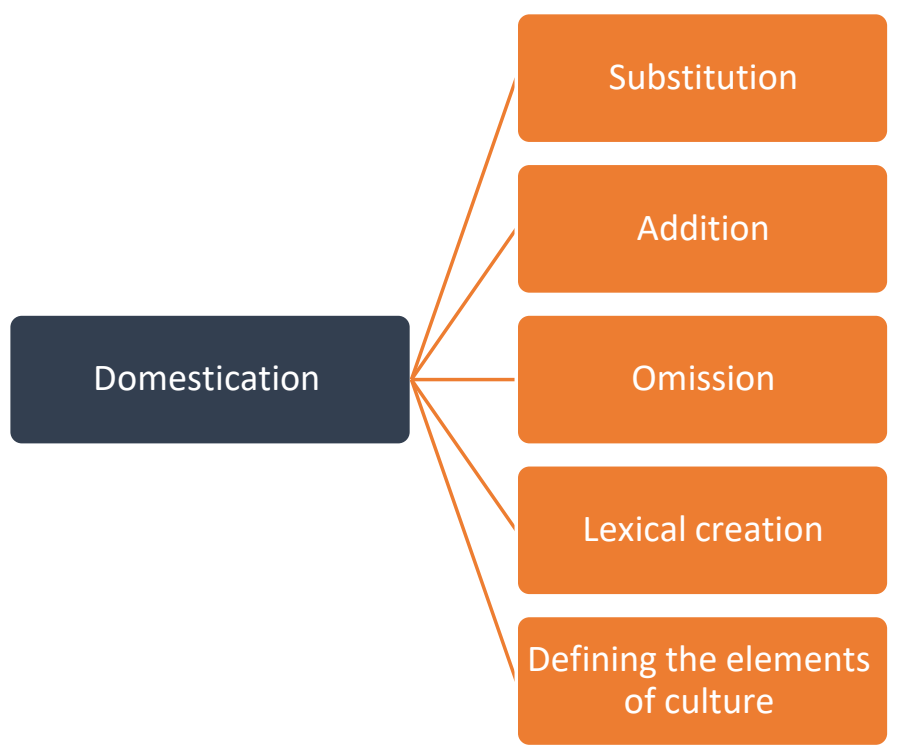

Figure two. Translation Procedures Domesticating the Text

\section{CBE One:}

ST: كبير القوم خادمهم

TT: the great man lives to serve his people, as they say

The expression "كبير القوم خادمهم has social and cultural connotations among Arabs. It can be classified as an idiom or saying used to show that the leader of any group of people; whether it is a nation, tribe, party or even family should serve his/her people since he/she is responsible for helping them and providing them with the things they need. If we look at the target text "the great man lives to serve his people, as they say", we notice that, according to Ivir (1987), the translator in this extract has resorted to translation by paraphrasing or defining the elements of culture. To paraphrase an idiom means to give a brief explanation, especially when finding a full or a partial equivalent is not possible in the TL. As it is mentioned in the introduction of this chapter, defining the elements of culture can be associated with domestication strategy. 
The translator in this extract has used the strategy of domestication which is applied in the procedure of defining the elements of culture. Using definition is good to explain the meaning, but by using "the great man" to translate "كبير القوم", the translator has not been able to convey the meaning intended by the original writer. The translator could have used the word "leader" instead of "the great man". Personally speaking, the expression "great man" does not convey the same connotative meaning of "كبير القوم" since if we make back translation we get "رجل عظيم", which is not what the original writer intended to mean.

\section{CBE Two}

ST: مسخرة

TT: it is a farce

The source text here is a word used when someone wants to deplore a situation or an idea in a sarcastic and silly way, and it is used when someone sees no logic in certain episodes; so he/she says it to express their total denial or refusal towards this thing or this incident. The translator here has used "It is a farce" as equivalent to "مسخرة". According to Wikipedia, "a farce" is "a comedy that aims at entertaining the audience through situations that are highly exaggerated, extravagant, and thus improbable. "Farce" is also "characterized by physical humor, the use of deliberate absurdity or nonsense, and broadly stylized performances. "Farce" is a literary term derived from a French word which is performed in the form of light and humorous plays; hence this term is part of the western literature and culture. The translator in this term has used the procedure of substitution finding a term in the target language that has an equivalent effect similar to the effect created on the original receptor. Being fully aware of the usage of the word "مسخرة: in the Arab context, the translator has successfully found an appropriate word in the target culture maintaining the function of the original term.

\section{CBE Three}

ST: قهوة العرس غير قهوة العزاء حيث تفقد القهوة السادة كل معانيها

TT: Coffee at wedding is different from coffee at a wake, when coffee loses all meaning

The source text discusses the habit of drinking coffee in different occasions in the source language culture, including weddings and mourning shelters. It is worth mentioning here the value and the importance of coffee in the Arab context, as Arabs have great interest in coffee. Coffee has become the symbol of hospitality in the Arab homes and gatherings. However, coffee does not get the same attention and value in the western culture, so this may create a gap in translation. If we look at the target text, the translator has translated "العزاء" into "a wake", but this is inaccurate; because according to Reverso context, awake means "تأبين", and in the Arabic culture we do not call the ceremonies of receiving condolences when someone dies "تأبين". What is exactly meant by "a wake" is, according to Merriam-Webster online dictionary, "a watch held over the body of a dead person prior to burial and sometimes accompanied by festivity". So the difference between "نأنبين" usually takes place at night before the burial of the dead person, and this term is not used in Islam, but it is used in other religions. One more difference is that lasts for more than one day; up to three days, unlike "تأبيت العزاء" which is organized in one day. In the translation above the translator uses the procedure of substitution which can be associated with domestication. He has replaced the term "عزاء" in the source culture with a culturally equivalent expression "a wake" which may have the same connotative meaning of 
"عزاء". This rendering, however, has not conveyed the intended meaning of the source language expression "عزء" "عزاء" "by saying "special ceremonies performed when someone dies to receive condolences" or use "mourning shelters" as a cultural substitution.

\section{CBE Four}

ST: حين تفقد القهوة السادة كل معانيها

TT: when coffee loses all meaning

The translator in this example has omitted the adjective " from the target text providing no equivalent for the cultural term. Again this is due to the fact that non-Arabs do not value coffee like Arabs, and they are not interested in the flavors of coffee, so the translator might think that the word " سادة" is not very important. So the procedure the translator has used in this example is omission, which can be fallen under the procedure of domestication strategies. The researchers think that this word is significant here because there are various flavors for coffee, and the "black coffee" which means "القهوة السادة" is the type of coffee that is served by Arabs at mourning houses.

\section{CBE Five}

ST: مطّة و عقالة

TT: Kufiya and the cord

The source text here includes two pieces of the traditional head cover " wطة و عقالة worn by Arab elderly males, particularly in the Levant. The traditional piece of cloth "حطة is an important part of the Arabic culture and heritage since it depicts the originality of Arabs. "حطة " has another name in the Arab context, which is "كوفية" "Kufiya". The translator here has borrowed the word "Kufiya" from Arabic language using the same pronunciation with English letters. He has preferred to borrow the word "Kufiya".which can be associated with foreignization in this extract, and putting the text within the context of the source culture. The term "Kufiya" is frequently used in English language since it has been recently used in many Arabic-English dictionaries. The researchers think that the translator has succeeded in using the word "Kufiya" as equivalent for "حطة"

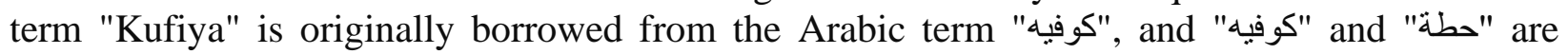
synonyms in Arabic language; so it is a perfect decision made by the translator to render "حطة" as "حطة" "Kufiya".

\section{CBE Six}

ST: عقال

TT: the cord

The term "عقال" is a band of fabric worn around the head to set the Kufiya. The translator has translated this word as "the cord" applying the procedure of substitution within the framework of domestication. "عقال" is a purely cultural word related to the Arab heritage as an integral part of their identity. The researchers think that the translator has not perfectly managed to translate this concept in an appropriate way. However, it would be better to use transliteration, e.g. "Aqal", and then provide a footnote explaining its meaning.

\section{CBE Seven}

$$
\text { ST: الخلايلة أجدع ناس }
$$


TT: The khalilis are great guys

The source text here is an expression used to praise someone or a group of people for their courage and loyalty. In this extract, the speaker addresses the people of al-Khalil, or Hebron, lauding them for their kindness and belonging. Generally, people of al-Khalil in the West Bank are known as simple and cooperative people. The translator here has rendered the word "الخلايلة as "khalilis" using the procedure of borrowing which comes under the strategy of foreignization. The researchers see that the translator has successfully rendered the word "الخلايلة"as "khalilis". Although the translator could use the English equivalent "Hebron", he has preferred to borrow the word and put the text within the source cultural context. In addition, the translator is a British translator, and he belongs to a different culture, the thing that makes us expect that he might use the English equivalent rather than borrowing it from the source language. Personally speaking, the target text should include some foreign and exotic features in order to enrich the target reader's knowledge and urge him/her to search and read more about this borrowed word, not just provide $\mathrm{him} /$ her with an exaggeratedly clear text. Moreover, "al-Khalil" is an old city known for its archeological sites, and it is an integral part of the Palestinian culture, so it is preferable to borrow this word from the original text in order to maintain the identity of this great city.

\section{CBE Eight

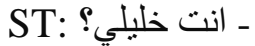

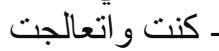 \\ TT: - Are you from al-Khalil? \\ - I used to but I got treatment}

The source text is a conversation between two persons about whether the addressee is from alKhalil (Hebron) or not. The answer here has been literally rendered into English that the addressee used to be Khalili, but he got treatment. It is worth mentioning here that the people of al-Khalil are said to be known for their stubbornness and naivety in the Palestinian society, so they are always liable to sarcasm. In addition, many jokes and humorous situations are told to mock their behaviors and reactions. The addressee's is a metaphor, as he depicts being khalili is an illness that he had in the past, but he got treatment from. He of course made this image to amuse listeners and add a sense of humor to the conversation.

The translator here has employed the literal translation procedure which can be associated with foreignization. However, using literal translation in this case is inappropriate. This extract needs more elaboration in order to be fully understandable and accessible in the target culture which is not using the same expression to describe the same situation. In the researcher's opinion, it is preferable if the translator has explained it in a footnote or paraphrased it to make the target reader aware of the relation between the question and the answer in this conversation; otherwise the reader will be confused and will not get the intended meaning of the source text.

\section{CBE Nine}

ST: والنعم

TT: An honor

The source text here is a culture-specific term said as a complement to praise someone's origin or behavior. For instance, if I tell someone that I am from Palestine, he/she can reply using this 
term to praise Palestine and its people. The translator here has substituted the source text with a word used in the target culture which has the same equivalent effect in the target context, e.g. "honor". For the sake of illustration, the translator has repeated the source language's text in the target text by using a parallel reference. Generally, the procedure of substitution aims to domesticate cultural references and keep the target reader adherent to his/her own cultural patterns and norms.

In this example the translator has used the method of substitution within the framework of domestication. He has maintained the same connotative meaning and render it to the target language considering the culture differences between the two languages regarding this term. Both terms, source and target terms, have the same implication, but each term suits the norms of its cultural framework. Needless to say, the ultimate goal of translation is to transfer meaning, not words.

CBE (10)

ST: مربعانية الثتاء

TT: forty eight days of the bitterest cold

The source text in this example is an expression used to describe the period of pretty cold weather in winter in the Arab world which lasts for forty days beginning in December, 22 till the end of February. Arabs usually, especially in the Levant, prepare themselves well to receive these days, in terms of wearing warm clothes, trying not to leave home during severe depressions and using heaters. The translator in this extract has domesticated the expression in the target language using the method of paraphrasing or defining cultural elements. Here the translator has rendered this expression maintaining the same functional meaning. The Arab world and the west, of course, have different climates; therefore, the translator has tended to use this procedure of defining the cultural element in order to convey the ST sense accurately by using descriptive translation in the target language.

\section{CBE (11)}

ST: الله يرمل مرتك يا صبحي

TT: God widow your wife

This extract is a colloquial insult used in the Palestinian society to express anger and discontent. Insults vary from one region to another and from one culture to another. This insult is an indirect one, which means that "I hope you die" so your wife becomes a widow, and it is used spontaneously without being conscious of its real meaning. In this example, the translator has used literal translation to render this colloquial expression into English as "God widow your wife", which can be associated with the foreignization strategy. The researchers think that the translator has failed to transfer this expression because as it is mentioned before that using insults differs from one culture to another, with each insult in each culture having different implications and connotations. So, adopting the literal translation method is not appropriate in this context. Personally, it would be better if the translator substituted this insult with another one which is more natural and accessible in the target culture e.g. "damn you".

Arab World English Journal for Translation \& Literary Studies 
CBE (12)

ST: صابون الثكعة وصابون طوقان

TT: Shak'a soap and Tuqan soap

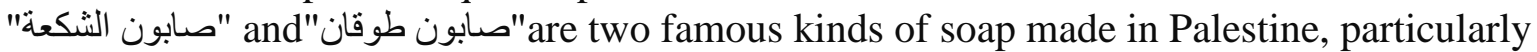
in the city of Nablus in the West Bank, using natural components. The main component of the Palestinian soap is olive oil, so many people prefer to use it rather than using chemical products of soap. The translator here has employed the procedure of borrowing which comes under the strategy of foreignization to render this example into English as "Shak'a soap, and Tuqan soap". By using the borrowing procedure, the translator has been able to give more details about these two kinds of soap since these kinds are locally made and produced, even Arabs who live outside Palestine may not know much about them. The researchers think that borrowing in this example should be combined with another procedure, such as defining the elements of culture and paraphrasing to give more appropriate explanation; for example, mentioning that "these soaps produced only in Nablus in the West Bank, Palestine and its chief ingredients are olive oil, water, and an alkaline sodium compound". This definition or elaboration can be given in the body of the text or in a footnote.

\section{CBE (13)}

ST: الله لم ينحسكم غيري, طول عمري منحوس

TT: It must be my fault, I'm unlucky by nature

The source text here is an expression derived from daily life of Arabs in general and Palestinians in particular. It is said when someone thinks the he has a bad luck, he/she always goes through bad episodes and circumstances, and this bad luck may affect people who are around this person. So if a bad thing happens, it is attributed to the bad luck of that person. The translator in this example has used literal translation to transfer the meaning into English. The translator has employed the method of literal translation within the frame work of foreignization, transferring the form and content into the TL. Here the translator has been able to render the source expression in an appropriate way which does not affect the original sense found in the source text because the two involved cultures have the same situation. As Newmark (1988) has said "a common object will usually have a one-to-one literal translation if there is cultural overlap" (p.70). Therefore, there are no ambiguous elements in this extract that need more elaboration in the cultural context of the target language. Moreover, if we use the back-translation method to ensure accuracy, we will get, to a large extent, the same original text.

CBE (14)

ST: مسخن

TT: Musakhan

"مسخن" is a traditional, Palestinian dish, being considered as one of the most popular dishes in Palestine. The essential ingredients of this recipe are chicken, onion, olive oil and sumac. Palestinians often prepare this dish for people who come from other countries and cultures to let them know more about their traditional food. The translator has borrowed this term from the source culture and rendered it in the target language as "Musakhan" adopting the strategy of foreignization. Traditional recipes are locally created, so it may be hard to find appropriate cultural equivalents in other cultures. CBEs are an example of non-equivalent words which are very 
problematic in the translation process. The source language term is not lexicalized in the target culture and the source-language word is semantically complicated. So the translator has resorted to use the procedure of borrowing in this example so as to maintain and preserve its local identity.

\section{CBE (15)}

ST: لو عا خايفة من هدير البحر, ماوقفنت عالثنط

TT: Had Acre feared the sea's roar, it would never had stood on the shore

The source text in this example is a metaphor of personification. The author here likens Acre, a Palestinian coastal city, to a human being who stands on the shore without being afraid of the rough sea. Newmark (1988) defines metaphors as a "figurative expression: the transferred sense of a physical word; the personification of an abstraction; the application of a word or collocation to what it does not literally denote, i.e., to describe one thing in terms of another" (p.105). The translator in this example has kept the same ST original metaphor in the TT using literal translation, one of the foreignization procedures since he retains the same semantic features of the ST metaphor. By doing so the translator has perfectly rendered this extract into English since he has kept the same image of the ST in the TT. The personification in the ST indicates that the people of the Acre city are very strong and they will always be steadfast despite the atrocious acts of the Israeli occupation, including the practices of displacement and bombing. So, maintaining the same metaphor in the TT enriches the meaning in an effective way rather than using explicit explanation which makes the text plain and boring.

\section{CBE (16)}

ST: طريقك خضر ا يا تميم

TT: Your road is blessed

The statement in this extract is an expression said to wish others good luck hoping that they succeed in their plans. The culturally loaded expression is derived from daily communication in Arab societies. The translator has translated this expression as "Your road is blessed" adopting the technique of substitution which comes under the strategy of domestication. Here the researchers believe that the translator has conveyed this source text into English achieving the same equivalent effect in the target text. It can be noticed here that literal translation cannot work at all because the meaning will remain vague in the target language. If we try to apply literal translation, we get "your road is green"; which may not make sense within the context of target culture. The green color in Arabic culture is a symbol of comfort and happiness, so Arabs use this color to wish their folk a happy life full of accomplishments. But some other cultures, including western culture, do not use this expression that includes the green color to express the same situation. Instead, the translator has used an alternative term in the target culture that has the same communicative meaning of the source text: this term is "blessed". To sum up, the translator has managed to capture the functional meaning of the source text in an appropriate way using the substitution technique.

CBE (17)

ST: الله يلعن الثيطان

TT: Damn it

This expression is said in the Arabic culture when someone is angry and upset, so he/she starts cursing the devil. The devil is the chief evil spirit and the reason of lack of success, especially in 
Islam, as Arabs unintentionally use this expression to express their displeasure and wrath. The translator here has used the procedure of substitution to render this cultural expression into English as "Damn it", which comes under the strategy of domestication. Translator has achieved the ultimate goal of translation process which is having the same cultural effect on the target readers as "Damn it" is a commonly used expression in western culture which is said in the same situation of the source culture, so this substitution has the same functional meaning in the target culture.

\section{CBE (18)}

ST: العتابا و الميجانا و الدلعونا

TT: Ataba, mijana and dal'ona

The source text here includes some traditional musical forms performed in the Arab world, particularly in Lebanon, Syria, Palestine, and Jordan."العتابا و الميجاناو الدلعونا" are celebratory musical forms sung at several occasions, such as weddings and festivals, and their lyrics are inspired by the surrounding cultural environment. As the translation above shows the translator has preferred to borrow these terms from the SL into TL and rendered them as "Ataba, mijana and dal'ona respectively employing the strategy of foreignization. These traditional types of singing are just restricted to the Arabic culture with oriental melodies which do not exist in the target culture; so the translator has employed the borrowing technique in order to preserve the identity of these forms.

CBE (19)

ST: هذا لوجها الله (19)

TT: Just like that, with no expectation of reward

The source text expression here is used when someone does not wait rewards from anyone, but he/she seeks God's reward, for example, when a person helps others or does them favors, he/she does not want anything in return, except God's reward. This is a quality that all Muslims should possess. It is apparent that this situation does not exist in the target culture because of different religions. The translator has domesticated this expression in the TL to overcome this dilemma using the procedure of paraphrasing or defining the cultural elements. By translating it as "Just like that, with no expectation of reward", the translator has perfectly captured the functional meaning of the ST and rendered it into the TL. As the researchers mentioned before, there is a gap between the two involved cultures regarding this extract due to religious differences. Therefore, the most appropriate technique to be used to render this expression is to clarify and explain it in the TL.

CBE (20)

ST: الجفت

TT: Smooth grindings

The source concept "الجفت in this extract means, according to Wikipedia, "a by-product from the olive oil mill extraction process. Usually it is used as fuel in a cogeneration system or as organic fertilizer after a composting operation". It is also used as fuel to ignite the clay oven in the Palestinian society to prepare bread. Based on the above discussion, this term is culturally loaded and often used in the Arabic culture. The translator has rendered the source term in this extract as a "Smooth grindings" applying the technique of defining the elements of culture within the framework of domestication. This method is frequently used in translating items between two languages belonging to distant cultures, such as Arabic and English. However, the researchers 
think that the translator had to explain the source concept in a more illustrative way because the target text here is very general and does not specify exactly the type of grindings intended in the source text. But what is meant in the source text is particularly the grindings of olive mill pomace, not any other kind. It would be better to translate "الجفت"as "olive mill pomace".

\section{CBE (21)}

ST: وجبة مسخن محترمة

TT: Musakhan meal

The researchers have earlier discussed the term "Musakhan" which is a traditional Palestinian dish consisting mainly of chicken, onion, olive oil and sumac. The source text here means "a hearty Musakhan meal". It can be noticed here that the translator has omitted the adjective "محترمة from the source text and translated it as "Musakhan meal" in the target language. Here the translator has employed the procedure of omission which can be categorized under the strategy of domestication. The researchers think that the word "محترمة"does not have a significant role in the target language; it is acceptable if it is deleted in the target text. In other words, the meaning of the source text is not affected by this omission because this adjective can be considered as a mere filler word as Arabs usually tend to use redundancy in their daily communication.

CBE (22)

ST: الهمة يا شباب

TT: pat your backs into it

The source text here is an encouragement said to motivate others to keep going without giving up very quickly. The target text here "pat your backs into it" is a common saying in the target culture used, according to the Collins Dictionary, "to boast about one's own skills or good qualities". Also, according to the Longman English Dictionary, it means "to praise someone or yourself for doing something well". It can be noticed here that the translator has rendered this expression using the technique of substitution, one of the domestication procedures. By using the substitution technique the translator has succeeded in rendering this extract into English because he has kept the same content using different words. By doing so, the translator has maintained the function of the source text in the target text. Moreover, when the translator uses a cultural substitute, i.e., an approximately culturally corresponding TL expression, this can be seen as enrichment and embellishment of the target text.

CBE (23)

ST: روح يا مريد يا ابن سكينة بنتي الله يعلي مر اتبك

TT: Go, Moried son of Sakina my daughter, may God elevate your rank.

The source text here is a prayer to God to elevate Moried's, the author of this autobiography, rank and standing among people. Arabs usually say such prayers as a kind and nice response to anyone offering them help, and sometimes they say such prayers without reason, just for God's sake. The translator in this example has used the procedure of literal translation which can be associated with foreignization. He has rendered it as "Go, Moried son of Sakina my daughter, may God elevate your rank" keeping each word of the source text without any omission. By adopting the technique of literal translation the researchers think that the verb "go" is not significant in the target text, as the translator has replaced the verb "روح"in the source text by the verb "go" in the 
target text, which is not important to be preserved in the TT. As it is mentioned earlier, Arabs like to use fillers in their conversations, and the verb "روح "رو is a filler word that does not carry any meaning, so it would be better if it is omitted for the sake of naturalness and idiomaticity.

\section{CBE (24)}

ST: الكنافة النابلسية

TT: Kanafa from Nablus

The source text in this example is a famous sweet in Palestine."الكنافة"is a favorite Palestinian dessert, crunchy shredded dough baked with a layer of creamy sweet cheese and then drenched in rosewater syrup. It is simple yet impressive. The cheese filling is traditionally made from Nabulsi cheese that is desalted. Nablus city is the most famous city in the West Bank for making Kanafa. The translator has used the technique of borrowing to translate this type of dessert, one of foreignization procedures; he has introduced it in the target language as "Kanafa from Nablus". Therefore, the translator has rendered this term maintaining its equivalent effect since this sweet is typically related to the Arabic culture; it is non-existent in the western culture. But at the same time, other cultures may now know about "Kanafa" because it is very famous around the world, so it is not necessary to combine borrowing with another method to provide additional explanatory notes for this term.

\section{CBE (25)}

ST:ذبحت خروف احتفالا

TT: She slaughtered a sheep in celebration

The sentence"ذبحت خروف احتفالا"has a religious reference. For example, when Muslims want to celebrate a very special occasion, they usually slaughter a sheep in celebration. These occasions include having a new baby, graduation and marriage. However, Muslims should follow the conditions for Halal slaughter established by Islam. This religious ritual is Sunna in Islamic Shari'a, and many cultures know about it. It can be noticed that the translator has adopted the technique of literal translation, which can be categorized under the strategy of foreignization, to transfer this example as "She slaughtered a sheep in celebration". In the light of the previous discussion, the translator's choice to use literal translation in such example is appropriate. This is because the meaning is clear and this CSE can be understood by several cultures as the researchers have previously mentioned. There is no need to paraphrase it or give extra explanation. Personally speaking, in some cases the translator should be faithful to the original text, as in this example.

\section{Discussion}

This thesis attempts to identify the most common strategies used in rendering cultural bound expressions in Barghouty's autobiography I Was Born There, I Was Born Here from Arabic into English. In addition, the researchers attempt to find out to what extent the translator has succeeded in choosing the translation strategies he used to maintain the meaning of the original cultural bound expressions. In brief, the researchers have selected 25 extracts of CBEs and analyzed them to answer the two main research questions of this study. 


\section{The First Question:}

In response to the first question (What are the most common strategies used in translating cultural bound expressions in Barghouty's autobiography I Was Born There, I Was Born Here from Arabic into English?) in terms of the application of the Venuti's model, the analysis in previous chapter indicates that (13) expressions or 52\% of the total items show the application of the domestication translation strategy and (12) situations or $48 \%$ of the total items have employed the foreignization translation strategy .

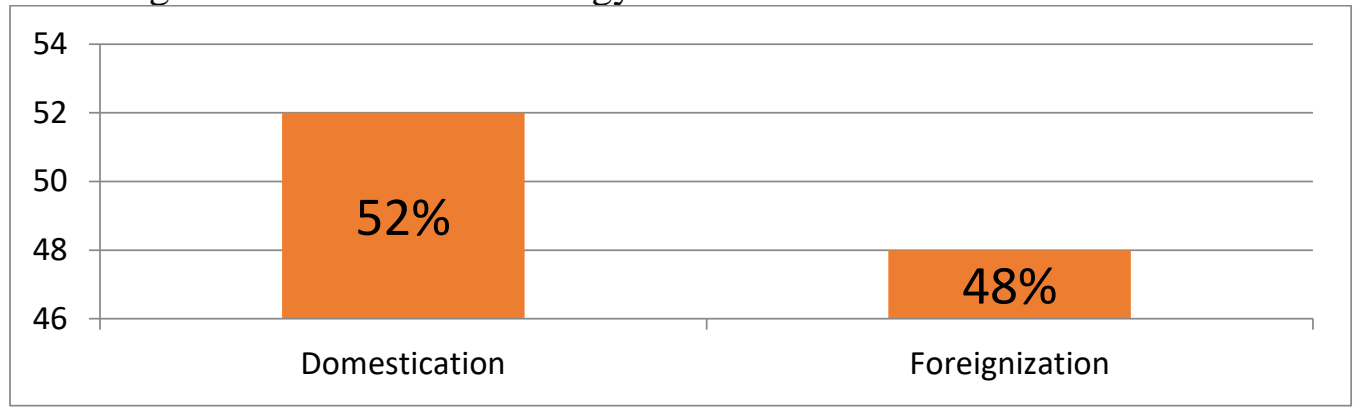

Figure three. Venuti's Strategies Used

The figure above shows the translator's intention to take the author towards the reader in order to reduce the foreignness of the TT, which can clearly be seen in the final percentage (52\%) with 13 examples. On the other hand, Humphrey Davies, the translator, has less tendency towards foreignization strategy, which can clearly be seen in the final percentage (48\%) with just 12 examples.

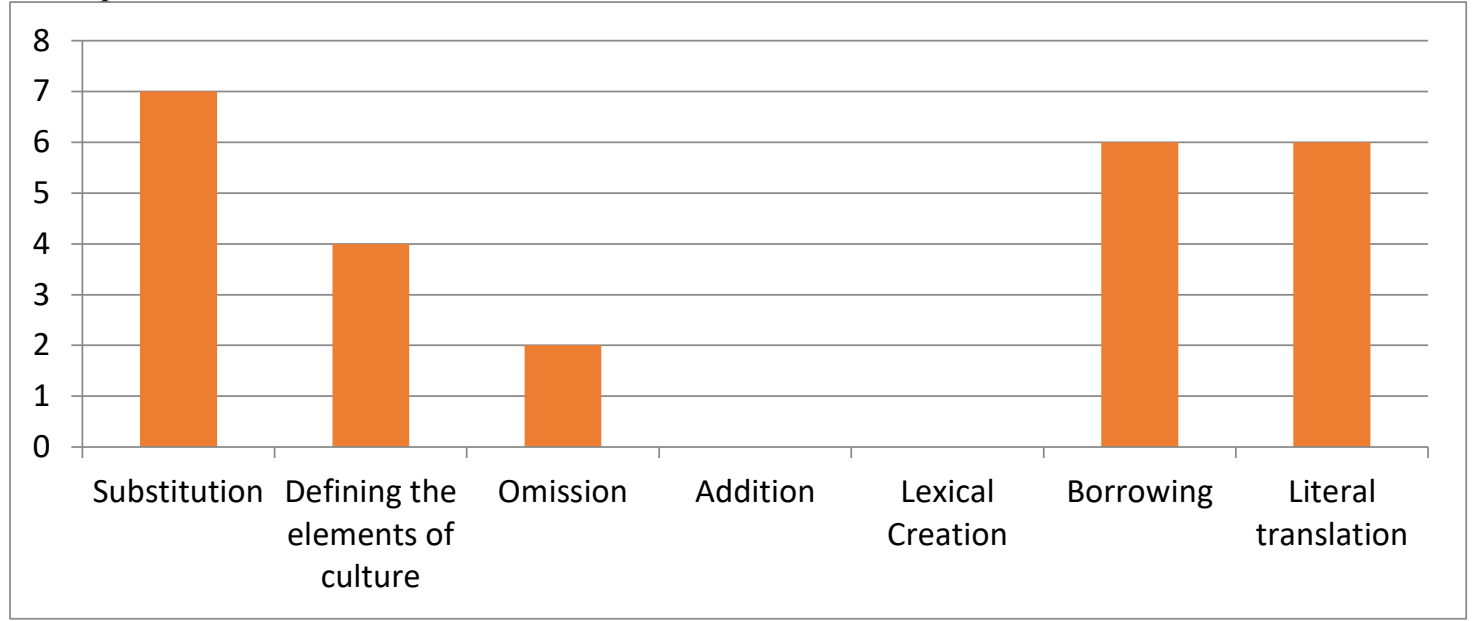

Figure four. Ivir's Procedures for the Translation of Cultural References Used

As can be seen above, substitution is the most frequently used procedure in dealing with culturebound expressions (seven times), one of domestication procedures, followed by literal translation and borrowing with the same number of times (six times) then defining the elements of culture (four times), then omission (twice). It can also be noticed that the lexical creation and addition have not been used at all. The high percentage of substitution procedure is attributed to the fact that the translator belongs to the target culture, so he is fully aware of his own culture, which in 
turn enables him to easily find substitutions for certain expressions within the Western target culture. The table in Appendix A summarizes all CBEs showing their translation and the strategies used.

\section{The Second Question:}

Question two is (To what extent has the translator succeeded in choosing the translation strategies he used to maintain the meaning of the original CBEs?). Table (1) shows that the translator of this literary work has succeeded in maintaining the meaning of the source CBEs in 18 examples accounting for $(72 \%)$, while he has not been able to convey the same meaning and the same equivalent effect of the source CBEs in 7 extracts accounting for $(28 \%)$. The translator has provided inappropriate translations in some examples, such as his translation of the two cultural terms "الجزاءت" and "الجن" because he has not been able to accurately understand the meaning intended by the original writer.

Table 1. Achieving cultural equivalence

\begin{tabular}{|l|l|}
\hline $\begin{array}{l}\text { Number of translated CBEs } \\
\text { appropriately rendered }\end{array}$ & $\begin{array}{l}\text { Number of translated CBEs } \\
\text { inappropriately rendered }\end{array}$ \\
\hline 18 & 7 \\
\hline $72 \%$ & $28 \%$ \\
\hline
\end{tabular}

\section{Conclusion:}

This thesis attempts to examine 25 extracts of cultural bound expressions in the English version of Barghouty's autobiography "I Was Born There, I Was Born Here", adopting Venuti's domestication and foreignization strategies and Ivir's procedures for the translation of cultural references. It aims at finding out the translation strategies that have been used to render the selected samples from Arabic into English.

The most important conclusions drawn out of the thesis are summarized as follows:

1- The domestication strategy has been the most frequently-used strategy in dealing with culturebound expressions in translating Barghouty's autobiography I Was Born There, I Was Born Here from Arabic into English; especially the procedure of substitution

2- The procedure of literal translation has ranked second (8 times) in terms of applying Ivir's procedures for the translation of cultural references. The researchers attribute this to the fact that literal translation is the safest procedure to use in order to avoid misunderstanding and, accordingly, mistranslation.

3- The translator has succeeded in rendering the intended meaning sought by the original author in most extracts. In other words, he has succeeded in understanding the ST very well before transferring it into the target text. However, the results also reveal that the translator has not been able in some examples to understand the meaning intended by the original writer, so he has provided inappropriate translations, such as his translation of the two cultural terms "العز اءعل and

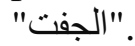

Arab World English Journal for Translation \& Literary Studies 
AWEJ for Translation \& Literary Studies Volume, 5 Number 4. October 2021

Investigating the Translation Strategies Used in Rendering Cultural

Ahmed \& Mansour

4-When the gap between two cultures is so huge, literal translation sometimes resulted in ambiguous translations; the thing that leaves the target readers confused. In other words, literal translation may not succeed in conveying the cultural connotations of some CBEs.

\section{About the Authors:}

Dr. Mohammed S. El Haj Ahmed is an associate professor of translation at the Islamic University of Gaza. He obtained his BA in English language and literature at the IUG in 1988, his MA in Applied Linguistics at the University of Khartoum in 1995, and his Ph.D. in Translation Studies at the University of Salford, UK, in 2009. Since 1997 Dr. El Haj Ahmed has been involved in teaching, supervising and publishing several papers on Translation and Interpreting. He also served as the head of the English Department.

Rola A. Mansour is a part time instructor at Gaza University. She obtained her BA in English language and Translation at Gaza University in 2013 and her MA in Translation Studies at the Islamic University of Gaza (IUG) in 2020. Mrs. Mansour worked as an interpreter for two years between 2013- 2015. She also worked as a freelance translator between 2015- 2018.

\section{References:}

Abbad, K. (2016). Cultural Manifestations in Literary Translation from Arabic into English and French: The Case study of the English and French Translations of Ahlem Mostaghanemi's novel Thakirat al-Jassad (Master's thesis), Canada: Concordia University.

Bush, P. (1998). Literary Translation. In: M. Baker. Routledge Encyclopedia of Translation Studies, 127-130, London: Routledge.

Gorjan, Z. (1970). On Translating Joyce's Ulysses. In J. Holmes (ed) The Nature of Translation Mouton, (pp. 201-207). Paris: The Hague.

Guerra, A.F. (2015).Translating Culture: Problems, Strategies, and Practical Realities. Journal of Literature. culture and literary translation, 3(1), 1-27.

Harvey, M. (2003). A Beginner's Course in Legal Translation: the Case of Culture-Bound Terms. Retrieved from: http://www.tradulex.org/Actes2000/harvey.pdf.

Ivir, V. (1987). Procedures and Strategies for the Translation of Culture. London: Routledge.

Newmark, P. (1988). A Textbook of Translation. New York and London: Prentice Hall.

Nida, E. A. (2001). Language and Culture-Contexts in Translation. Shanghai: Shanghai Foreign Language Education Press.

Nida, E.A. (1964). Towards a Science of Translating. Leiden: E.J Hall.

Nord, C. (2001). Translating as a Purposeful Activity - Functional Approaches Explained. Shanghai: Shanghai Foreign Language Education Press.

Sapir, E. (1949). Culture, Language and Personality. California: University of California.

Shuttleworth, M. \& M. Cowie (1997). Dictionary of Translation Studies. Manchester: St Jerome Publishing.

Venuti, L. (1998). Strategies of Translation. In M. Baker (ed.), Encyclopedia of Translation Studies. London and New York: Routledge.

Appendix A: Translation strategies used to translate the selected sample

Arab World English Journal for Translation \& Literary Studies 
AWEJ for Translation \& Literary Studies Volume, 5 Number 4. October 2021 Investigating the Translation Strategies Used in Rendering Cultural

Ahmed \& Mansour

\begin{tabular}{|c|c|c|c|c|}
\hline No. & CBE (ST) & Translation (TT) & Strategies used & $\begin{array}{l}\text { Achieving full } \\
\text { cultural } \\
\text { equivalence }\end{array}$ \\
\hline 1 & كبير القوم خادمهم & $\begin{array}{l}\text { The great man lives to } \\
\text { serve his people, as they } \\
\text { say }\end{array}$ & $\begin{array}{l}\text { Defining the } \\
\text { elements of culture }\end{array}$ & No \\
\hline 2 & مسخرة & It is a farce & Substitution & Yes \\
\hline 3 & قهوة العرس غير قهوة العزاء حيث القهادة كليثا & $\begin{array}{l}\text { Coffee at wedding is } \\
\text { different from coffee at } \\
\text { a wake, when coffee } \\
\text { loses all meaning }\end{array}$ & Substitution & No \\
\hline 4 & حيث تفقد القهوة السادة كل معانيها & $\begin{array}{l}\text { when coffee loses all } \\
\text { meaning }\end{array}$ & Omission & No \\
\hline 5 & حطة & Kufiya & Borrowing & Yes \\
\hline 6 & عقال & the cord & Substitution & No \\
\hline 7 & الخلايلة أجدع ناس & $\begin{array}{l}\text { The khalilis are great } \\
\text { guys }\end{array}$ & Borrowing & Yes \\
\hline 8 & ـ كنت واتعالجت ـانت خليلي؟ & $\begin{array}{l}\text { - Are you from al- } \\
\text { Khalil?- I used to but I } \\
\text { got treatment }\end{array}$ & Literal translation & No \\
\hline 9 & إلنعم & An honor & Substitution & Yes \\
\hline 10 & مربعانية الثتاء & $\begin{array}{l}\text { Forty eight days of the } \\
\text { bitterest cold }\end{array}$ & $\begin{array}{l}\text { Defining the } \\
\text { elements of culture }\end{array}$ & Yes \\
\hline 11 & الله يرمل مرتلك با صبحي & God widow your wife & Literal translation & No \\
\hline 12 & صابون الثكعة وصـابون طوقان & $\begin{array}{l}\text { Shak'a soap and Tuqan } \\
\text { soap }\end{array}$ & Borrowing & Yes \\
\hline 13 & و الله لم ينحسكم غبري طول عمري & $\begin{array}{l}\text { It must be my fault, I'm } \\
\text { unlucky by nature }\end{array}$ & Literal translation & Yes \\
\hline 14 & 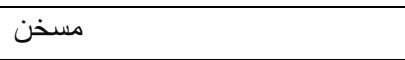 & Musakhan & Borrowing & Yes \\
\hline 15 & $\begin{array}{l}\text { لو عكا خايفة من هدير البحر, مالثط } \\
\text { وقنش عالثش }\end{array}$ & $\begin{array}{l}\text { Had acre feared the sea's } \\
\text { roar, it would never had } \\
\text { stood on the shore }\end{array}$ & Literal translation & Yes \\
\hline 16 & طريقاك خضر ا يا تميم & Your road is blessed & Substitution & Yes \\
\hline 17 & الله يلعن الثيطان & Damn it & Substitution & Yes \\
\hline 18 & العتابا و الميجانا و الدلعونا & $\begin{array}{l}\text { Ataba, mijana and } \\
\text { dal'ona }\end{array}$ & Borrowing & Yes \\
\hline 19 & هكذا لوجه الله & $\begin{array}{l}\text { Just like that, with no } \\
\text { expectation of reward }\end{array}$ & $\begin{array}{l}\text { Defining the } \\
\text { elements of culture }\end{array}$ & Yes \\
\hline 20 & الجفت & Smooth grindings & $\begin{array}{l}\text { Defining the } \\
\text { elements of culture }\end{array}$ & No \\
\hline 21 & وجبة مسخن محترمة & Musakhan meal & omission & Yes \\
\hline 22 & الهمة يا شباب & Pat your backs into it & Substitution & Yes \\
\hline 23 & روح يا مريد يا ابن سكينة بنتي الله & $\begin{array}{l}\text { Go, Moried son of } \\
\text { Sakina my daughter, } \\
\text { may God elevate your } \\
\text { rank }\end{array}$ & Literal translation & No \\
\hline
\end{tabular}

Arab World English Journal for Translation \& Literary Studies 
AWEJ for Translation \& Literary Studies Volume, 5 Number 4. October 2021 Investigating the Translation Strategies Used in Rendering Cultural

Ahmed \& Mansour

\begin{tabular}{|l|l|l|l|c|}
\hline No. & CBE (ST) & Translation (TT) & Strategies used & $\begin{array}{l}\text { Achieving full } \\
\text { cultural } \\
\text { equivalence }\end{array}$ \\
\hline 24 & الكنافة النابلسية & Kanafa from Nablus & Borrowing & Yes \\
\hline 25 & ذبحت خروف احتفالا & $\begin{array}{l}\text { She slaughtered a sheep } \\
\text { in celebration }\end{array}$ & Literal translation & Yes \\
\hline
\end{tabular}

Arab World English Journal for Translation \& Literary Studies 